\title{
POPULATION TRENDS ON THE TERRITORY OF THE CZECH REPUBLIC
}

Z. P a v lík: Population Trends on the Territory of the Czech Republic. - Sborník CGS, 99, 2,pp. $101-110$ (1994). - The process of demographic revolution had specific features on the territory of the Czech Republic. It started in the first half of the 19th century and ended between Two World Wars. The course of this process corresponded with the geographical position of Czech Lands in Europe. The demographic situation after the World War II was affected unfavourably by the political appurtenance of former Czechoslovakia to the Soviet block, especially in the field of mortality.

KEY WORDS: Czech Republic - population - population trends - demographic revolution.

In periods of great political and social changes which started in Europe since the 19th century the population trends can serve as one of their indicators. In the background of changes in the demographic reproduction there is a large and manysided process connected with the last stadium of civilization; it is often named as modernization or global revolution of modern time. While the first concept understands modernization as an uncomplete and continuos process (in spite of the fact that one speaks sometimes about post-modernism), the global revolution has been conceived as a historical process with more or less precisely specified beginning and end. In both cases, however, we see this process as a very complex one which consits of many partial processes mutually interrelated and conditioned. Many questions remain here for further research and many are not satisfactorily answered. What kind of impulses led e.g. to the transition from antemodern societies towards modernization and why this process started in Europe?

In connection with the demographic reproduction, the centre of our interest will be the demographic revolution as a part of the global revolution. The internal conditioning of the demographic reproduction leads to the steady repetition of its character; only fundamental changes in its economic, social, geographic and ecologic environment caused revolutionary changes in the character of demographic reproduction, sometimes named less tellingly as the demographic transition. At the end of demographic revolution the demographic reproduction stabilizes again on the qualitatively new level. Also fundamental changes in other processes with people can be qualified as revolutions - urbanization, extensive migration, the rise of mega-cities and large urban agglomerations, industrialization and many others as partial processes of the global revolution of modern time.

The origin of global revolution can be looked for in the European Renaissance and in the break-up of feudalism, followed by the Enlightenment with its tendency toward individualism, an emphasis on the idea of universal human progress and the free use of reason, and by the National Revival. All these are very complicated processes to be grasped in their complexity. However, it is possible to discern and document the advance of them in Europe from the North-West to the East-South. If we understand the meaning of demographic changes, demographic data can substitute information about more complex social and economic processes. 


\section{Position of the Czech Lands in the process of demographic revolution}

Demographic revolution has been usually characterized by the dramatic decrease of mortality and fertility levels; it has, however, much profound content than that: it signifies the revolutionary changes in the reproductive behaviour of people which have never occured in the past and will not be repeated in the future. The extensive character of demographic reproduction changed into the intesive one. Demographic data can indicate only the beginning and the end of this process. Therefore crude rates are sufficient for the first look: the crude death rate decreased from levels over 30 per thousand to less than 15 , and the crude birth rate from over 40 to less than 20 per thousand.

The above mentioned situation is well documented by data collected in tables 1 and 2. France and Sweden represent countries with the early start of the demographic revolution, Czech Lands (since January lst, 1993, the Czech Republic) are in the middle of this process in Europe, and Hungary, Poland and Romania form the end of the row. There are many specific features which stir up our interest. The mortality situation has been slightly better in Sweden than in France during the whole 19th century. However, the birth control started clearly in France already in 18th century. The end of demographic revolution can be put in-between Two World Wars for France, Sweden and Czech Lands, and only after the World War II for Hungary, Poland and Romania. The rather small difference between mortality and fertility levels in France indicates a small population growth during this process (the French type of demographic revolution) in comparison with Sweden with a cosiderable population growth (the English type of demographic revolution). Czech Lands (CL) have been somewhere in-between.

Table 1 - Crude Death Rate in Selected European Countries

\begin{tabular}{|ccccccc|}
\hline Period & France & Sweden & CL & Poland & Hungary & Romania \\
\hline $1785-1800$ & - & - & $32-33$ & - & - & - \\
$1801-1830$ & $25-28$ & $24-28$ & $28-38$ & - & - & - \\
$1831-1870$ & $25-28$ & $20-24$ & $28-31$ & $30-35$ & - & - \\
$1871-1900$ & $21-24$ & $16-20$ & $26-30$ & $28-31$ & $29-35$ & $28-31$ \\
$1901-1914$ & $18-19$ & $14-15$ & $20-22$ & $21-24$ & $22-25$ & $25-26$ \\
$1920-1939$ & $16-17$ & $11-12$ & $13-15$ & $15-18$ & $15-19$ & $19-23$ \\
$1950-1990$ & $9-11$ & $10-11$ & $10-13$ & $8-11$ & $11-14$ & $9-11$ \\
\hline
\end{tabular}

Table 2 - Crude Birth Rate in Selected European Countries

\begin{tabular}{|ccccccc|}
\hline Period & France & Sweden & CL & Poland & Hungary & Romania \\
\hline $1785-1800$ & $37-38$ & - & $43-44$ & - & - & - \\
$1801-1830$ & $31-32$ & $31-35$ & $40-42$ & - & - & - \\
$1831-1870$ & $26-29$ & $31-33$ & $38-39$ & $43-44$ & - & - \\
$1871-1900$ & $22-26$ & $27-31$ & $36-38$ & $42-43$ & $41-47$ & $40-41$ \\
$1901-1914$ & $20-21$ & $23-26$ & $21-33$ & $37-41$ & $30-36$ & $40-41$ \\
$1920-1939$ & $15-22$ & $15-18$ & $16-22$ & $27-33$ & $21-28$ & $31-39$ \\
$1950-1990$ & $15-19$ & $12-15$ & $13-18$ & $17-24$ & $12-19$ & $16-24$ \\
\hline
\end{tabular}

The mortality picture can be complemented by data about infant mortality rates and life expectancy. Infant mortality rates were around 250 per thousand the whole 19th century in the Czech Lands, life expectancy 35 years for both sexes in 1869-80 while in France it was already 40 years in the first half of the 19th century. It is not without interest that life expectancy was on the territory of the Czech Lands close to 30 years already in the 9th century; it has changed very little during the past millenium. The 
infant mortality rate decreased to 154 per thousand in 1920-24, to 96 in 1935-39, to 47 in 1950-54, to 20 in 1970-74 and to 9 per thousand according to the last available data. Life expectancy increased to almost 60 years by the end of demographic revolution and to 70 years in the beginning of 1960's. It stagnated since at the level of 67 years for men or even decreased in certain years, and it reached 68 years only recently; a steady small growth for women from 73 to 76 years during the same period cannot change the negative evaluation of the mortality situation during the communist era. Czech Lands were not the exception; a similar situation was in other former socialist countries - Hungary and Russia are good examples.

The mortality improvement during the demographic revolution did not occur equably in all regions and in all social strata. Towns and big cities were usually ahead as well as better off groups of population. Similar situation was in the field of fertility. The larger the country the bigger differences could have been expected. The decline of crude birth rate in the first half of the 19th century was due mainly to postponement of mariages and to the increase of the age of primiparae. The decline of the marital fertility started only in its second half. It can be well measured by the Coale's index of marital fertility (Ig) based on inderect standardization. As it can be seen on the Fig. 1, the marital fertility decline started in the Northern Bohemia and in Prague, i.e. in industrial regions with a higher share of urban population; in some of these districts there was predominantly German population with broad links with German regions of Saxony.

The end of the demographic revolution in a broader context of Central and Eastern Europe is clearly demonstrated on the Figures 2, 3 and 4. The Czech Lands together with Germany and Austria belong among countries, where the crude birth rate decreased below 20 in-between Two World Wars. They were followed by the majority of other countries in Eastern Europe after the World War II (Fig. 3) and only in Albania this process did not end yet in 1980's (Fig. 4).

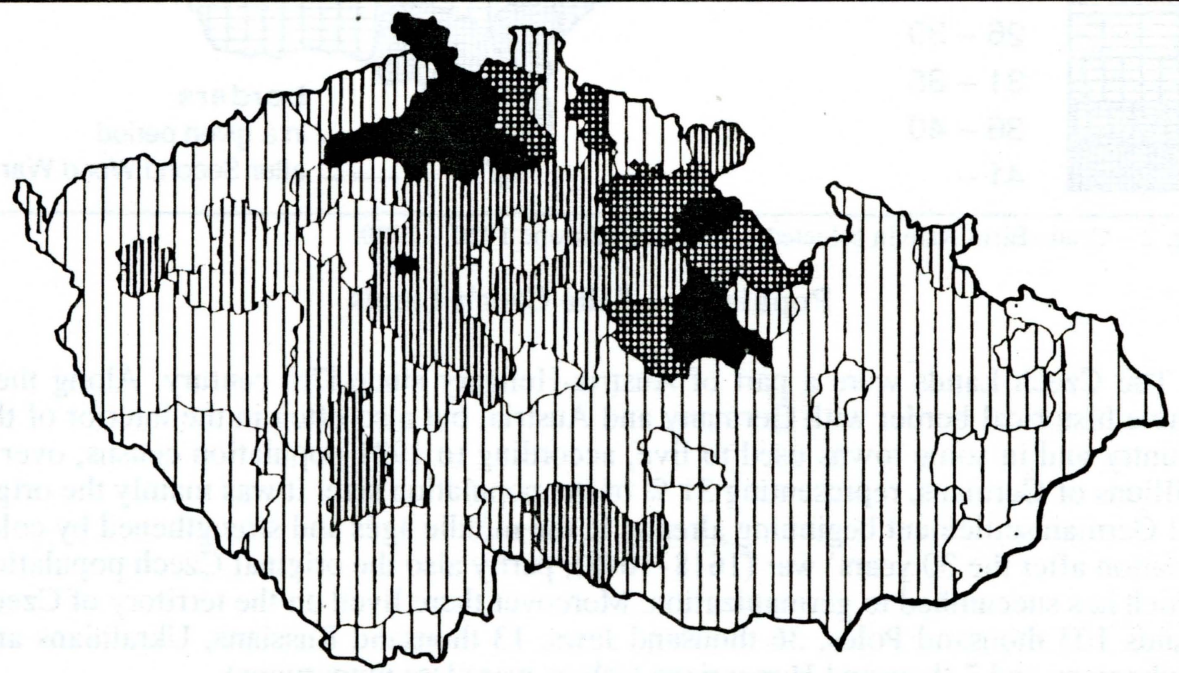

The start of the decrease

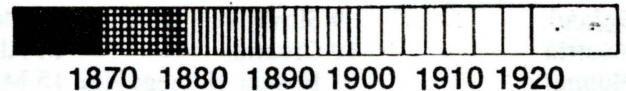

Fig. 1 - Beginning of the marital fertility decrease (Ig) on the territory of the Czech Republic. 


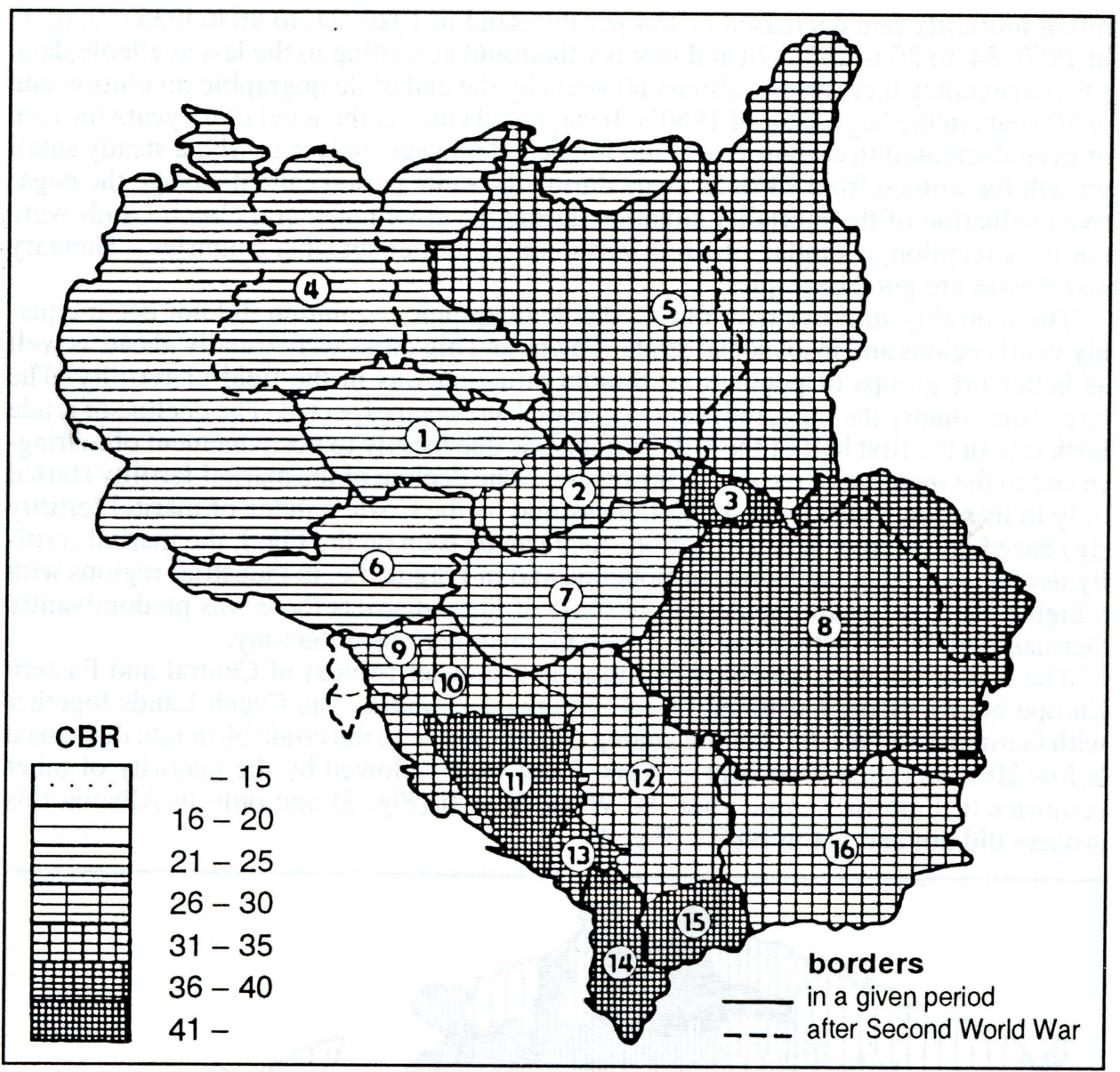

Fig. 2 - Crude Birth Rate in selected countries in Europe 1920 - 1929.

\section{Population of the Czech Lands}

The Czech Lands were a part of Austria-Hungary since 17th century. Along their whole historical border with Germany and Austria, but also often in the interior of the country and in some towns used to live, according to 1921 population census, over 3 millions of Germans, representing $31 \%$ of the population size. It was mainly the original German settlement beginning already in the middle ages and strengthened by colonization after the 30 years' war (1618-1648), partly also the original Czech population which has succumbed to germanization. Moreover there lived on the territory of Czech Lands 103 thousand Poles, 36 thousand Jews, 13 thousand Russians, Ukrainians and Ruthenians and 7 thousand Hungarians (others were less numeruous).

\begin{tabular}{|lccc}
\multicolumn{2}{l}{ Selected European Countries in maps 2,3 and $4:$} & \\
1 Czech Lands & 5 Poland & 9 Slovenia & 13 Montenegro \\
2 Slovakia & 6 Austria & 10 Croatia & 14 Albania \\
3 Ruthenia & 7 Hungary & 11 Bosnia-Herzegovina 15 Macedonia \\
4 Germany & 8 Romania & 12 Serbia & 16 Bulgaria \\
4'Former GDR & & &
\end{tabular}




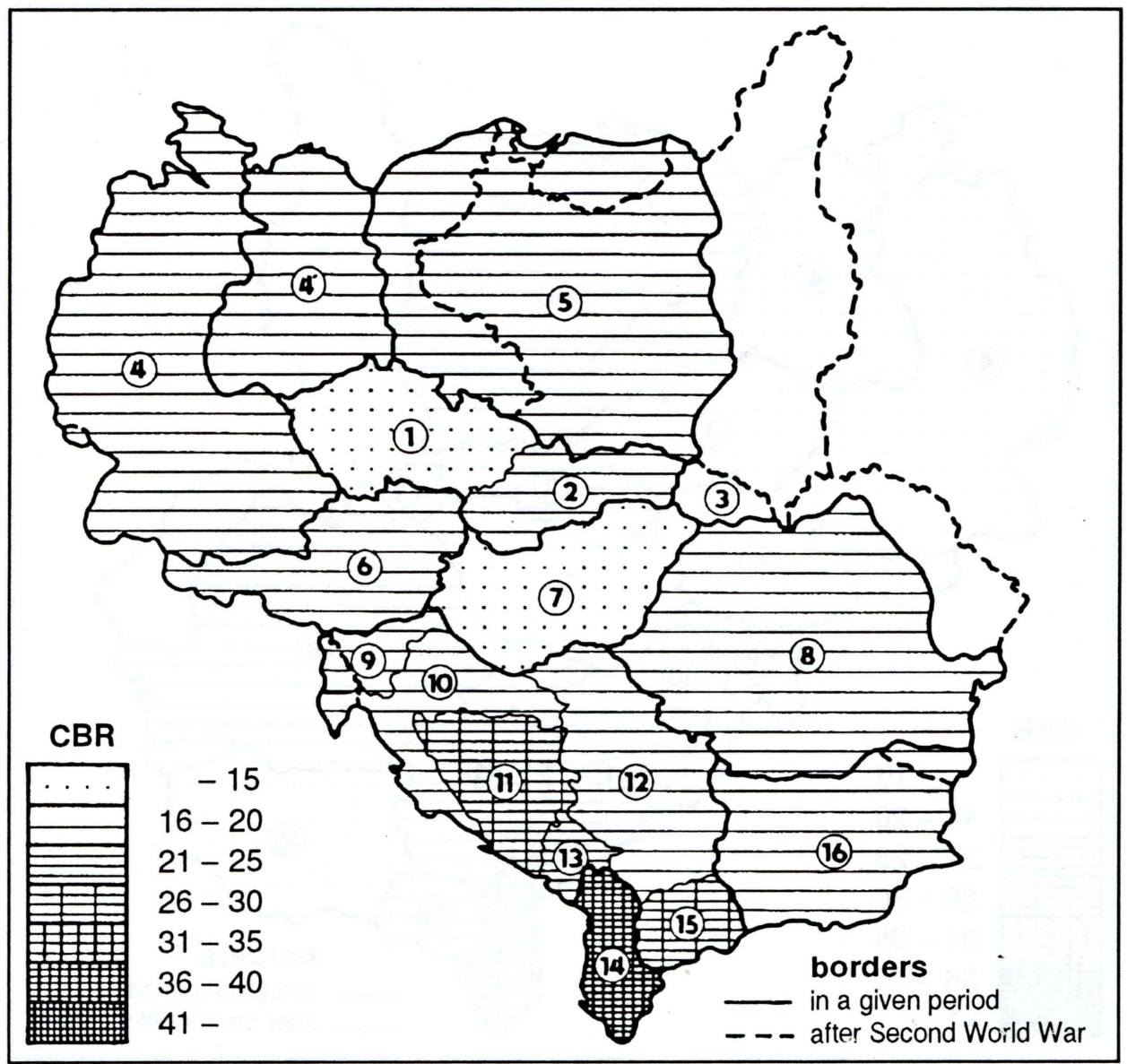

Fig. 3 - Crude Birth Rate in selected countries in Europe 1960 - 1969.

Population of the Czech Lands belongs to those, where significant emigration was taking place already before the year 1880 . This year is sometimes considered as a dividing line between the "old" European emigration of 19th century and the "young" emigration from Southern and Eastern Europe. In the period 1900-09 the Czech Lands lost 314 thousand of persons by emigration. In the interwar period the differential method based on the 1921 and 1930 population censuses gives a certain idea about the volume of migration. Bohemia gained 31 thousand during this period, Moravia and Silesia lost 93 thousand the total net migration being the lost of 62 thousand. Part of emigrants from Moravia and Silesia moved to Bohemia.

National structure of the Czech Lands changed considerably after the Second World War. In accordance with the decision of superpowers at the Potsdam conference the majority of German population was transferred out of the country (2 870 thousand including runaways before the organized evacuation); only about 200 thousand Germans had stayed. The war losses were not extremely high on the territory of the Czech Lands in comparison with neighbour countries: there were 55 thousand executed and violently deceased and the majority of Jews perished in concentration camps. After the displacement of Germans the Czech Lands became nationally homogeneous: 94 per cent of inhabitants declared the Czech nationality in 1950 population census; there were 258 


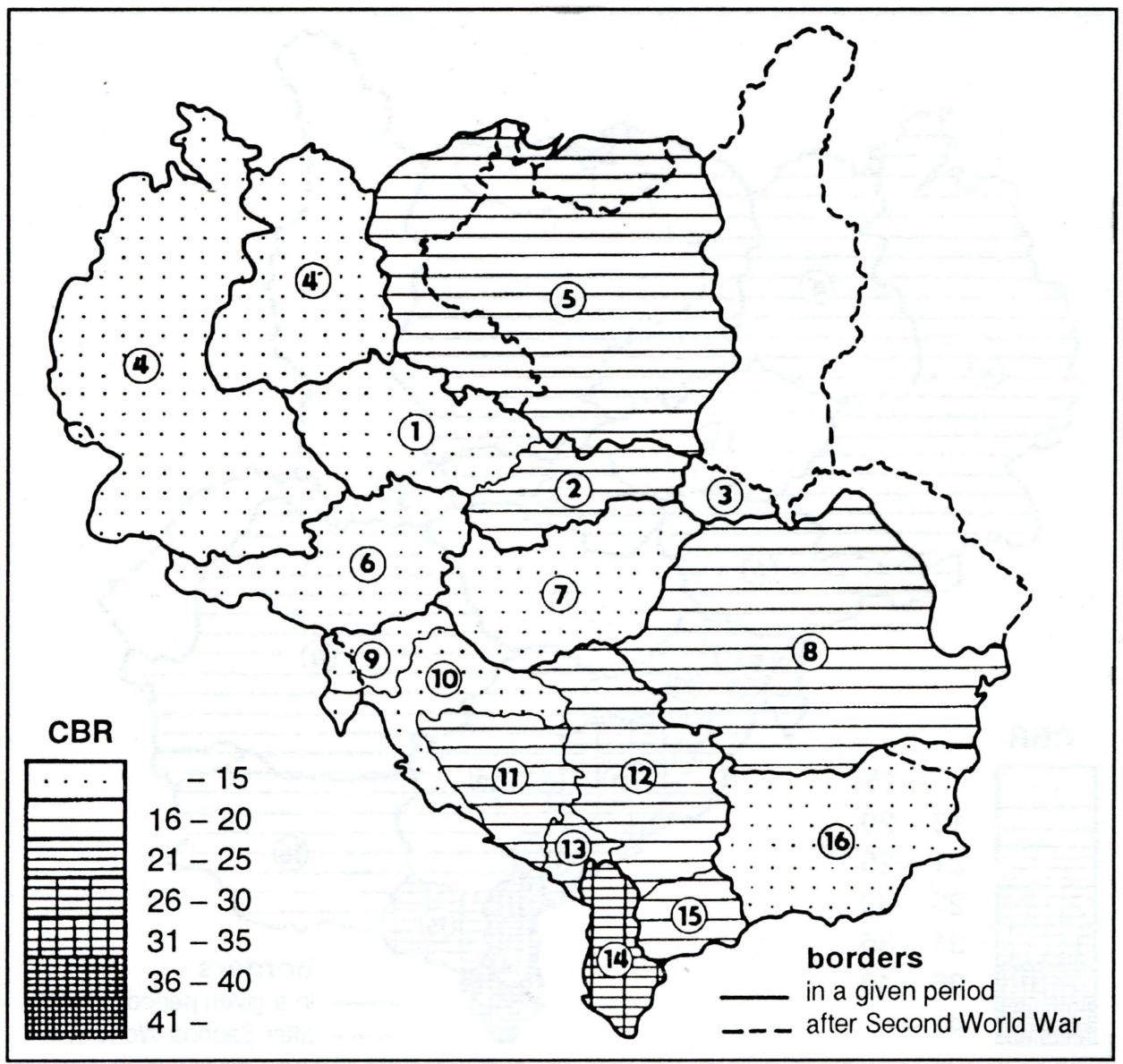

Fig. 4 - Crude Birth Rate in selected countries in Europe 1980 - 1989.

thousand (2.9\%) Slovaks, 160 thousand (1.8\%) Germans and from the rest 71 thousand declared Polish nationality. During the whole period up to 1991 the national structure of the Czech Lands changed very little. Only the number of Slovaks increased by immigration; they came firstly looking for job and they were 359 thousand (3.5\%) in 1980; their number decreased to 315 thousand $(3.1 \%)$ in 1991 , mainly because a part of them declared Romany nationality (the total number of Romanies in the Czech Lands can be estimated at around 150 thousand).

Table 3 - Population of the Czech Lands in Selected Years

\begin{tabular}{|lccc|}
\hline Year & $\begin{array}{c}\text { Population } \\
\text { in thousand }\end{array}$ & $\begin{array}{c}\text { Census } \\
\text { Year }\end{array}$ & $\begin{array}{c}\text { Population } \\
\text { in thousand }\end{array}$ \\
\hline 1840 & 6369 & 1950 & 8896 \\
1860 & 7256 & 1961 & 9572 \\
1880 & 8222 & 1970 & 9808 \\
1900 & 9372 & 1980 & 10292 \\
1930 & 10678 & 1991 & 10302 \\
\hline
\end{tabular}


Table 4 - Territory and Population of the Czech Lands (population census 15.2.1921)

\begin{tabular}{|lccc|}
\hline Land & $\begin{array}{c}\text { Population } \\
\text { in thousand }\end{array}$ & $\begin{array}{c}\text { Area } \\
\text { in sq.km }\end{array}$ & $\begin{array}{c}\text { Density } \\
\text { per 1 sq.km }\end{array}$ \\
\hline Bohemia & 6671 & 52100 & 128 \\
Moravia & 2663 & 22300 & 119 \\
Silesia & 672 & 4400 & 152 \\
Czech Lands & 10006 & 78800 & 127 \\
\hline
\end{tabular}

The steady growth of the Czech Lands' population in 19th and 20th centuries was interrupted only once after the World War II due to the displacement of Germans. The Czech Lands did not reached yet the number of inhabitants they had in 1930's, i.e. 60 years ago (table 3 ). The Czech Lands were also loosing population by emigration for political reasons after the War. Two emigration waves after 1948 and 1968 meant the loss of 340-370 thousand of people.

\section{Contemporary demographic situation}

The history of every population is hidden in its age structure. This holds also for the population of Czech Lands (Fig. 5). The effect of lower intensity of mortality among women in comparison with men can be clearly seen at the top of the age pyramid (1).

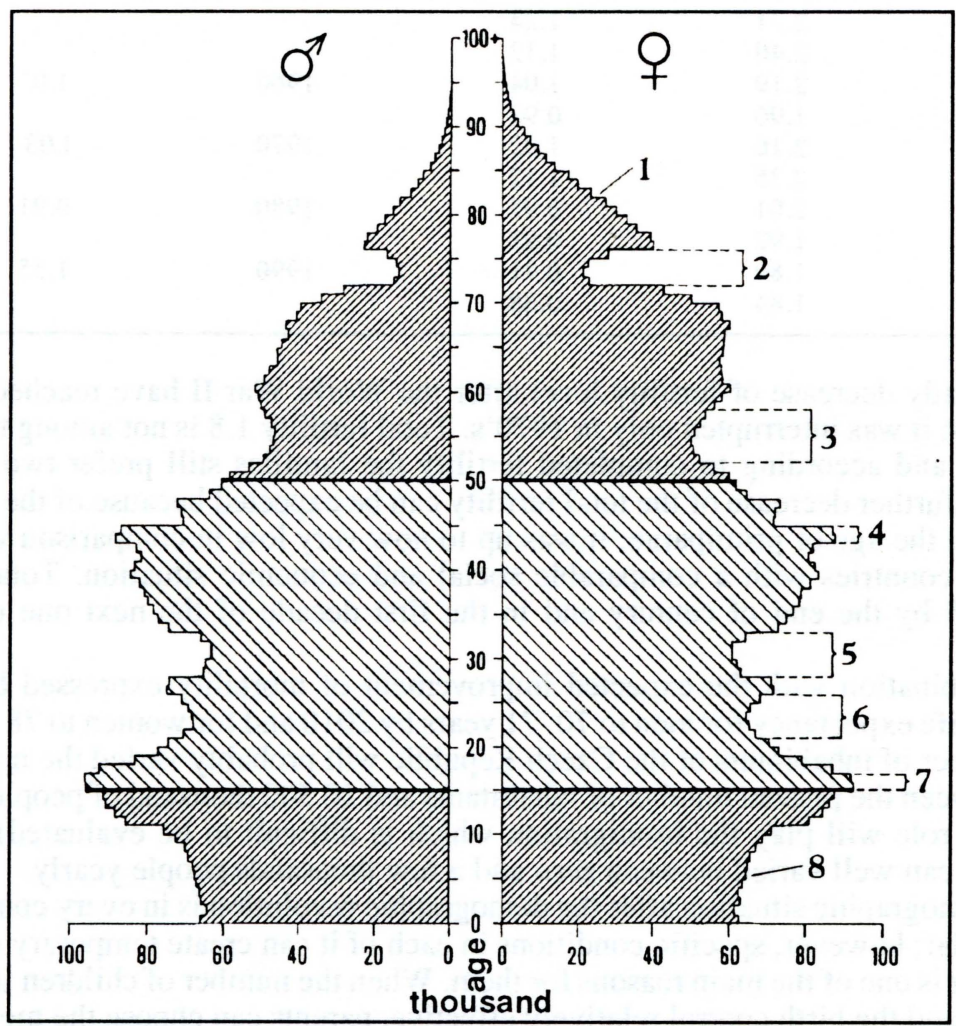

Fig. 5 - Age structure of the Czech Republic (3.3.1991). Explanation of numbers in the text. 
There are considerably more women than men already over the age of 60 ; over the age of 90 there are several times more living women than men. This different sex and age specific mortality has in every society many unfavourable consequences. The population of the Czech Lands was deeply affected by the unborn children during the first World War (2). Such a baby bust was never levelled and it influenced the number of live births 20 years afterwards. In connection with the world economic crisis and the European political instability this led to a new baby bust in 1930's (3). The baby boom after the War lasted only two years and was not extremely high (4); the birth rate was increasing already during the War. A new relatively low numbers of live births came during 1960 's following the liberalization of abortions in $1958(5,6)$. This could have strenghten the tendency but the real reasons have to be looked elsewhere. Two years with slightly higher numbers of live births in-between is an effect of tightening up the procedural regulations of the abortion law. The increase of the number of live births after 1969 with a peak in 1974-75 can be explained in different ways (7). Rather important population policy measures were accepted but at the same time a certain return to family life was noted after the Soviet invasion to Czechoslovakia. The expectation were lost and the political scene stabilized, although in a negative sense. The steady decline of the number of live birth in 1980's will probably continue in the future (8).

Table 5 - Population reproduction in the years 1950-1991

\begin{tabular}{|c|c|c|c|c|}
\hline $\begin{array}{l}\text { Period/ } \\
\text { Year }\end{array}$ & $\begin{array}{c}\text { Total } \\
\text { Fertility }\end{array}$ & $\begin{array}{l}\text { Net Repro- } \\
\text { duction Rate }\end{array}$ & Year & $\begin{array}{c}\text { Total Abor- } \\
\text { tion Rate }\end{array}$ \\
\hline $\begin{array}{l}1950-54 \\
1955-59 \\
1960-64 \\
1965-69 \\
1970-74 \\
1975-79 \\
1980-84 \\
1985-89 \\
1990 \\
1991\end{array}$ & $\begin{array}{l}2.71 \\
2.40 \\
2.19 \\
1.96 \\
2.16 \\
2.35 \\
2.01 \\
1.92 \\
1.89 \\
1.84\end{array}$ & $\begin{array}{l}1.24 \\
1.12 \\
1.04 \\
0.92 \\
1.02 \\
1.12 \\
0.95 \\
0.92 \\
0.91 \\
0.88\end{array}$ & $\begin{array}{r}1960 \\
1970 \\
1980 \\
\quad 1990\end{array}$ & $\begin{array}{l}1.0 ? \\
1.03 \\
0.91 \\
1.55\end{array}$ \\
\hline
\end{tabular}

The steady decrease of fertility level after the World War II have reached recently low values; it was interrupted only in 1970's. Total fertility 1.8 is not among the lowest in Europe and according to completed fertility the families still prefer two children. However, further decrease of the total fertility can be expected because of the supposed increase in the age of primiparae; it was up to now very low in comparison with other European countries with a comparable social and economic situation. Total fertility around 1.5 by the end of century and in the first decade of the next one cannot be excluded.

In combination with the expected improvement of mortality expressed by the increase of life expectancy for men to $70-71$ years by 2010 and for women to 78 years, the total number of inhabitants of the Czech Republic will probably varied the next twenty years between the present number of inhabitants and 10500 thousand of people (a rather important role will play the immigration which is difficult to be evaluated). The net migration can well varied between zero and a few thousands people yearly.

The demographic situation after the demographic revolution is in every country basically similar; however, specific conditions in each of it can create temporary differences. Timing is one of the main reasons for them. When the number of children in families is limited and the birth control relatively effective, parents can choose the most favourable time for the birth of their children and so they can be very much affected by the 
overall economic, social and political situation. Also their personal and health situation is changing and this cannot stay without effect on their reproductive behaviour. Economic transformation after the velvet revolution and the renewal of political democracy are very important positive events but they can have negative influence on the family decision to have a child at a given moment.

\section{Conclusion}

Population living on the territory of the Czech Lands - presently the Czech Republic - underwent the process of demographic revolution in accordance with its place in Europe. It differs presently together with other former socialist countries from remaining European countries, mainly in the worse mortality situation; its improvement is, however, expected. The total number of inhabitants will probably stabilize at the present level or slightly increase, but even the negative growth after 2000 is not excluded. Net migration can affect the population growth considerably; it is difficult, however, to be predicted with a sufficient reliability.

\section{References:}

ALEŠ, M. (1993): Populační vývoj v ČSFR v roce 1992 (Population development in the CSFR in 1992). Demografie, vol.35, No.4, 225-235.

FIALOVĀ, L., PAVLIK, Z., VEREŚ, P. (1990): Fertility Decline in Czechoslovakia During the Last Two Centuries. Population Studies, vol.44, 89-106.

PAVLIK, Z (1990): General and specific features of the reproduction after demographic revolution. Acta Universitatis Carolinae-Geographica, No.2, 29-36.

PAVLÍK, Z. (1991): Les tendances démographiques longues en Europe de 1'Est. Population, No.2, 463-478.

PAVLÍK, Z. (1991): La Tchécoslovaquie. In: European Population, INED Paris, 191-208.

\section{Shrnutí}

\section{POPULAČNÍ VÝVOJ NA ÚZEMÍ ČESKÉ REPUBLIKY}

Demografická reprodukce je poměrně velmi stabilní a biologicky podmíněný proces, který probíhá $v$ ekonomickém, sociálním a politickém okolí. Kdyby nedocházelo ke změnám v tomto okolí, neměnil by se ani proces demografické reprodukce. $\mathrm{K}$ takovým změnám však $\mathrm{v}$ prüběhu posledních několika staletí došlo - nazýváme je modernizací nebo globální revolucí moderní doby - a jejich dủsledkem byla i demografická revoluce. Tento proces bývá obvykle charakterizován poklesem úrovní plodnosti a úmrtnosti a prodloužením naděje dožití. Vystiženy vhodnými ukazateli mohou sice vystihnout počátek a konec uvedeného procesu, ale zakrývají jeho hlubší charakter, který tkví v podstatných změnách $v$ demografickém chování populace. Demografická revoluce je též změnou extenzivního typu demografické reprodukce $v$ typ intenzivní.

Průběh demografické revoluce je možno sledovat jako difúzní proces. V Evropě začíná ve Francii a šiŕi se ze západu a severu na východ a jih. V současné dobẽ pouze $v$ Albánii probíhá druhá fáze demografické revoluce, charakterizovaná poklesem úrovně plodnosti, $v$ ostatních evropských zemích ho lze považovat za skončený. Situaci od třicátých let ve změnách v úrovni plodnosti vystihuji pripojenené mapy $2-4$.

Počátek poklesu úrovně plodnosti na území Ceské republiky je možno sledovat na mapě l. Data za celou zemi vždy představuji prủměr rủzných regionů, města a venkova, sociálních a profesních skupin. U nás začíná pokles úrovně plodnosti v oblastech Prahy a Liberce. Naopak jižní Cechy a Morava se opoždují.

Na území České republiky žilo podle sčítání lidu v roce 1921 více než 3 mil. Němcủ, kteří tvořili více než $30 \%$ obyvatelstva. V dủsledku odsunu po druhé světové válce jich zủstalo jen asi 200 tis. 
a obyvatelstvo české národnosti tvoňi nyní $94 \%$. Menšinou jsou Slováci $(3,1 \%)$, Němci, Romové a Poláci.

Demografická historie české populace je dobře patrná z obr. 5. Płevaha žen ve vyšších ročnících věkové struktury charakterizuje nadúmrtnost mužu již od 60 let, ale zvláště výrazně ve vyšších věkových skupinách. Nepravidlenosti věkové struktury byly zpủsobeny dále malým počtem narozených $v$ průběhu první světové války, poklesem úrovně plodnosti ve třicátých letech, jejím vzestupem po druhé světové válce a následnými změnami populačního klimatu koncem sedesátých a v první polovinę sedmdesátých let. V současné dobẽ zaznamenáváme dalši pokles úrovně plodnosti. Lze očekávat, že se její úroveñ přiblí̌í situaci v západoevropských zemích. Pokud jde o úroveñ úmrtrosti, lze též ozekávat jeji dalši zlepšováni, avšak pravděpodobně velmi pomalé. Vzhledem k tomu, že je obtižné odhadnout saldo mezinárodní migrace, jsou i prognózy budoucího populačního vývoje Ceské republiky méně spolehlivé. Lze očekávat stabilizaci počtu obyvatelstva na současné úrovni, avšak nelze vyloučit ani jeho mírný pokles po roce 2000.

Obr. 1 - Začátek poklesu manželské porodnosti (Ig) na území České republiky.

Obr. 2 až 4 - Hrubá porodnost ve vybraných zemích Evropy v obdobích 1920 - 1929, 1960 - 1969 a 1980 - 1989. CBR - hrubá míra porodnosti. (Zakresleny jsou hranice z meziválečného období i současné.)

Obr. 5 - Věková struktura obyvatelstva Ceské republiky k 3.3. 1991. 